Relations industrielles

Industrial Relations

\title{
Administrative Financial Management, Joseph F. Bradley, Holt, Rinehart and Winston, Inc., New York, 1963, 612 pages.
}

\section{Laurent Bélanger}

Volume 19, numéro 4, 1964

URI : https://id.erudit.org/iderudit/027530ar

DOI : https://doi.org/10.7202/027530ar

Aller au sommaire du numéro

Éditeur(s)

Département des relations industrielles de l'Université Laval

ISSN

0034-379X (imprimé)

1703-8138 (numérique)

Découvrir la revue

Citer ce compte rendu

Bélanger, L. (1964). Compte rendu de [Administrative Financial Management, Joseph F. Bradley, Holt, Rinehart and Winston, Inc., New York, 1963, 612 pages.] Relations industrielles / Industrial Relations, 19(4), 527-527.

https://doi.org/10.7202/027530ar

Tous droits réservés @ C Département des relations industrielles de l'Université Laval, 1964
Ce document est protégé par la loi sur le droit d'auteur. L’utilisation des services d'Érudit (y compris la reproduction) est assujettie à sa politique d'utilisation que vous pouvez consulter en ligne.

https://apropos.erudit.org/fr/usagers/politique-dutilisation/ 
Evaluation des Emplois - Collection Travail (no 4), Editions de la Baconnière, Neuchôtel, 1963, 110 pages.

Comme le volume l'indique, «il suffit de s'occuper de fabricotion industrielle pour cpercevoir l'importance du rôle que jouent, chacun le soit, les problèmes de choix, des critères de choix: sur quelle base orienter une qualité donnée ou sur quoi fonder un toux pratique de travail?

Le volume se divise en trois parties principoles:

1 - Lo présentation d'une méthode d'évaluation basée sur le système de points.

2 - Les précautions d'ordre social et d'ordre méthodologique qu'il fout prendre dans l'application d'un système d'évaluation.

3 - Un cotologue de fonctions-types qui contient à la fois la description et l'évoluation de ces fonctions.

Lo méthode présentée dons le volume est acceptable mais peut difficilement s'appliauer intégralement dans une entreprise. Du fait qu'on a voulu développer un même système pour les employés rémunérés à I'heure et des employés rémunérés ou mois, on a introduit des critères ou des degrés qui ne s'appliquent pas intégralement à chacun des deux groupes. Par ailleurs on remarque certains chevauchements d'un critère d l'autre, comme Capacités intellectuelles et Initiative nécessaire.

Toutefois, indépendamment de ces remorques, la méthode d'évaluation présentée dans le volume est un excellent canevas à partir duquel on peut élaborer un système d'évaluation pour un groupe donné dans une entreprise particulière.

L'originalité du volume, et ce qui le distingue des outres volumes en la motière, vient du fait qu'il contient une présentation impressionnante de tôches que l'on rencontre habituellement dans I'industrie. Chacune de ces tôches possède une excellente description et on retrouve à la fin une évaluation de ces tôches d'après la méthode présentée ou début du volume.

Lò encore il ne foudroit pos qu'une entreprise s'avise d'appliquer intégralement cette évaluation, mais elle peut très bien s'en inspirer afin d'en arriver à une hiérarchisation acceptable des postes.
Administrative Financial Management, toseph F. Brodley, Holt, Rinehart and Winston, Inc., New York, 1963, 612 pages.

Here is a new approach in the field of financial management. The area of business finance is broodened and integrated in the over-all administration of the firm. Finoncial monagement encompasses the mojor functions that characterize general administration.

Once the ordinary financiol concepts and the forms of organization hove been recalled, the outhor goes into the planning process: planning the gools of the firm, the use of circulating and fixed capital; planning for expansion through an estimate of the cost of capital, and a ranking of the projects in terms of their respective profitability.

Directing the use of copitol and showing the role of each financial instrument constitute the second phase of this overall administrative process. Controlling or $a p$. praising the use of capital is the last phose.

Hod the author dealt with the organization of a financial department, he would have completed the tosk he ossigned to himself. The organizing phase has been left aside. Moreover, this approach de-emphosized the specific role of the financial manoger. Profitability versus liquidity force the financial manager to face a duality of objectives and to strike a balance in ochieving both. However, the author made a remarkable effort to facilitate the understanding of the text by supplementing it with concrete, illustrative and down-to-earth examples. Unhappily, by doing this, he avoids most of the crucial and controversial issues about the cost of copital and the ranking of investment proposals according to the method used. Illustrations are based on an implicit theorizing which is impossibie to detect. For instance, he concludes that under certain circumstances it would be advantogeous for the common stockholders to have the corporation issue convertible bonds instead of common stock. This policy will olso permit the corporation to lower its cost of capital. This view is not accepted in «academic financial circles».

Probably the author did not want to bring up those theoritical issues and made an attempt to facilitate the task of the students in the field of finance. If this is so, the book is a success. 